This is the last fraft of this article after the refereeing process and just before publication.

Hürol, Y., (2013) "On Ethics and the Earthquake Resistant Interior Design of Buildings." Science and

Engineering Ethics. Vol:20. No:1. pp.171-181. DOI 10.1007/s11948-012-9424-1.

\title{
ON ETHICS AND THE EARTHQUAKE RESISTANT INTERIOR DESIGN OF BUILDINGS
}

Yonca Hurol

Ethics means being open for change.

Alain Badiou

\begin{abstract}
The most common tectonic quality of modern structures, such as frame systems, is their flexibility; they are open for change. Although this characteristic is a big advantage in comparison to the inflexible masonry structures of the past, it might also create some serious problems, such as e.g. the lack of safety in the event of an earthquake, if the flexibility is not used consciously by architects and interior designers. This article attempts to define and establish some rules for the interior design of buildings with reinforced concrete frame systems. The rules for making subtractions from these structures and extending them by making additions to them are contained within this article. The main objective of this article is to derive some ethical values from these rules. Thus, the conclusion of the article focuses on the derivation of some ethical values for achieving earthquake resistant interior design of buildings with reinforced concrete frame systems.
\end{abstract}

Keywords: earthquake resistant design, interior design, flexibility, structural engineering, reinforced concrete frame.

\section{INTRODUCTION}

"Recent earthquakes have caused unacceptably high death tolls... reducing such an unacceptably high loss of life from earthquakes is the most important challenge facing the global earthquake engineering community..." (Comartin, Brzev, Naeim, et al., 2004) Steinbrugge stated in 1982 that the $20^{\text {th }}$ century death toll due to the 26 earthquakes, which had magnitudes between 6.0 and 8.6, was around 1,5 million. Since this problem is not caused only by the structural engineers, professional strategies against earthquakes should include all parties within the design team of buildings: architects, structural engineers and interior architects.

Architecture relates to time through change and change in architecture is the basic task of interior design. People need to change their buildings according to their changing needs. If a building is designed for change, its structure is seen as a separate level, which is not necessary to change, whilst changing the other parts of the building. (Habraken, 1998; Leupen, 2005) Thus, change does not affect the earthquake resistance of these buildings negatively. However, if change is not planned, then it can cause serious earthquake resistance problems, because the structure is not accepted as a separate "level" and it is manipulated according to the requirements of the new interior design concept. 
This article focuses on buildings, which are not designed for change and discusses the criteria of the earthquake resistant interior design of such buildings, which have reinforced concrete frame structures. It is known that reinforced concrete frame structures with rigid infill walls form a very critical typology in respect of earthquakes. There are earthquake reports and specifications showing that many reinforced concrete buildings collapsed due to irregularity problems, which are a result of bad design, due to bad construction or due to bad interior design. (Paz, 1994; ITU, 1999)

The research objective of this article is to formulate the basic rules of achieving the earthquake resistant interior design of buildings with reinforced concrete frame structures and to derive some ethical design values for those professions, which are involved in this building process; viz architects, structural engineers and interior designers. The issues of legality and bureaucracy, as e.g. in the activities of professional chambers and municipalities, are not covered by the scope of this article.

Actually, talking about the rules of structural design for architectural purposes is a very old approach. Rules were valid for the design of traditional masonry buildings before modern architecture and before the use of frame structures. (Mainstone) Frampton (2001: p.5) states that we can only talk about the tectonics of modern buildings, but buildings with masonry structures can have 'stereotomics' ('stereos` to solid and 'tomia to cut) but not tectonics. Modern tectonics has always been seen as the area of freedom in the designing process because of the existence of frame structures with their elementary nature, lightness and flexibility of their partition walls. (Billington, 1983; Leatherbarrow, Mostafavi, 2005) However, after spending a century with these modern frames and after facing many practical problems, as well as having equally valid success stories, it is realistic to start thinking about the necessity for some rules, especially in respect of the issue of earthquake resistant interior design. Freedom should not be understood as just doing anything without being aware and conscious of what is being done. (Kavas, 1996)

Traditional rules were broken only by the greatest masters and on the basis of the demands of kings and sultans. (Aran, 2000; Goodwin, 1993) However, modern rules should be breakable by any designer, as long as the problem created by the broken rule is compensated for. Thus, the rules defined within this article are not like unbreakable traditional rules. Rather, they should be seen as breakable rules, if the designer is working consciously and with awaraness. Having such rules is useful, because they relate theory to practice. This makes theory more pedagogic and suitable for teaching and using in practical designs.

It is very healthy for architects, interior designers and structural engineers to discuss the ethics of design in relation to the rules of making changes in a specific type of building, because change is the basic reality of practical life in buildings and it involves all related professions as responsible parties within this action.

There is a large volume of literature on the subject of the earthquake problems of frame structures (Athanassiadou, 2008; Ambrose, Vergun, 1985; 1995; 1999; Dowrick, 1990; Hu, Li, Dong, 1996), frames with masonry infill (Ravichandran, Klingner, 2012-12-02), strengthening or retrofitting frame structures (Kaushik, Rai, Jain, 2009; Martinezrueda, Elnashai, 1995; Miller, Reaveley, 1996; Warner, 1996), experience gained through specific cases of earthquakes (such as ITU, 1999) and earthquakes as a city planning problem. (Charleson, 2009) However, there is a gap in the literature in respect of earthquake problems due to changes in architecture as a result of the interior design of a building.

There is also literature on professional ethics in architecture and structural engineering. (Martin, Schinzinger, 2005; Pultar, 1997; 2000) However, these do not consider the issue of change in buildings. This article is an original work, because it works on this gap and it adapts the old idea of rules to the professional ideology of modern design within the three related professions.

The author of this article is an architect who has taught structures to architecture and interior architecture students for 28 years. These courses have been taught as "tectonics" courses rather than classical statics, strength, structural analysis courses during the last 8 years. They are also related to design studios. The author of this article also teaches design, attends to design juries and has the opportunity of relating the theory of structures to the design practice of architecture and interior architecture. Thus, the methodology of collecting 
and evaluating data to write this article can be defined as an active observation within a long teaching experience of structures and design.

The article contains five headings: The nature of interior design from the point of view of structures, the rules of making subtractions from the existing structure, the rules of making additions to the existing structure, the methods of compensating for the broken rules and a discussion on the ethics of designing buildings with reinforced concrete frames for all related professions.

\section{THE NATURE OF INTERIOR DESIGN FROM THE POINT OF VIEW OF STRUCTURES}

The architectural design of structures is usually seen as the addition of pieces of structure to each other. These pieces can be similar to each other, or they can also be very different from each other. It is possible to have many bays of frames added to each other to form a 3D frame. It is also possible to add domes and vaults to frames. (Lin, Stotesbury, 1981) However, structural design in interior design, which creates extension systems, (Mornement, 2007) cannot only be explained by adding structures to each other. Since the object of interior design is an existing building, it becomes possible or necessary to subtract pieces from the existing building structure. Interior designers usually imagine the subtractions first and then design the necessary additions.

It has been observed that the problems associated with earthquakes, which arise in the design projects of interior architecture students, can be categorised into two groups:

a. Problems due to the subtractions made from the existing building structure,

b. Problems due to the additions made to the existing building structure.

Thus, the rules of earthquake resistant interior design should also contain rules in respect of subtraction from the existing building structure and rules of addition to the existing building structure.

\section{ON SUBTRACTIONS FROM THE EXISTING BUILDING STRUCTURE}

Observation of the student projects show that there is a large variety of subtraction problems in interior design. All elements of the buildings can be subtracted by the students; columns, beams, slabs, stairs, rigid infill walls and light-weight infill walls.

Actually all of these actions are possible, if the technology available is fully utilised, if there is official permission and if the client is prepared to pay for the cost of this. Even during the first half of the $20^{\text {th }}$ century, La Maison de Verre, which was a masonry building, was elevated with the help of a temporary structure and a frame structure was built underneath it in order to meet the demands of a bohemian family. (Neumann, Cowan, Compain, n.d.) Many rules, which are set within this article, were broken within this project. However, this was done consciously and the broken rules were compensated for. This approach to change was holistic in its nature. Not only were one or two columns removed but the construction process was also seen as a part of design. On the other hand, studio projects in interior design education do not usually assume conditions as such. Although they are more realistic in many issues, they might ignore structural problems for the sake of teaching the art of design. This is part of the professional ideology of design, which is transferred to students during design education. (Stevens, 1998)

If there are restrictions in the budget of the project, if there are no special official permissions and if the technology to be used is limited, then it is possible to list the rules of subtraction in interior design as follows:

a. No columns and beams should be subtracted,

Even if the building is not in an earthquake region, subtracting columns will disturb the structure. There might be other columns sitting on that column. The beams, which transfer their load to that column, do not have sufficient depth and reinforcement to carry their new load without that column. If vertical elements of a structure are removed, then they have to be replaced somehow as in the case of La Maison de Verre. 
Even if the building is not in an earthquake region, the subtraction of beams will disturb the formation of the frames, the connection between the frames and the way slabs are supported. Having continuous frames from one side to the other side of the buildings is a very important requirement in respect of the issue of earthquake resistance. (Ministry of Public Works and Settlement Government of the Republic of Turkey , 2007)

Such problems can be discussed for each particular structure. However the general reason for not removing columns and beams from a structure is the rule, which forms the base of professional ethics: All buildings must be built according to the professional projects, which were designed for them. The only way of not following this rule is to prepare another set of professional projects, which will enable the required change. (Martin, Schinzinger, 2005; Pultar, 1997; 2000)

b. A slab can be removed as a whole or a small piece of it can be subtracted. In any case, before deciding to make changes in slabs, it is necessary to get advice from a structural engineer.

Reinforced concrete slabs have reinforcement in them. If the majority of the reinforcement in one direction is cut, this causes a radical change to the original composition of the slab, which is according to the professional projects. On the other hand, removing many slabs from a building can also change the earthquake resistance of that building, because slabs work as diaphragms connecting vertical elements in the structure. The removal of slabs can stop the structure from behaving as a unit. (Dowrick, 1990) Unless only small holes in the slabs (eg. to pass pipes) are required to be made, the professional advice of a structural engineer is required, since more reinforcement is required when larger holes are made.

c. Stairs can be subtracted, if their removal does not weaken the remaining parts of the existing structure. Before deciding to remove stairs, it is necessary to get advice from a structural engineer.

Stairs represent sculptural artistic elements for interior designers. Whenever there is an interior design project, the old stairs are usually removed and new more artistic ones are added. (Mornement, 2007) The stairs designed by interior designers always have light-weight structures. The major problem in removing the old stairs and adding the new one arises in relation to the role of the old stairs within the original structure. For example, if it is located within a staircase tower, then removing the stairs and leaving a hollow tower, damages the structure of that tower. Thus, it is again necessary to get advice from a structural engineer before removing stairs.

d. Rigid infill walls can be removed if this action does not create a soft/weak storey or twisting instability problems. Before deciding to remove rigid infill walls, it is necessary to get advice from a structural engineer.

There is a preconception amongst architects, interior designers and laymen that the removal of the infill walls does not affect the building structure. Thus, they are usually removed without getting any advice. However, removal of rigid infill walls can cause vertical irregularity and plan irregularity problems, which are also known as soft/weak storey and twisting instability problems. (Kirac, Dogan, Ozbasaran, 2011; Jeong, Elnashai, 2007; Lee, Woo, 2002; Negro, Verzeletti, 1996; Papia, Cavaleri, Fossetti, 2003) Thus, the removal of rigid infill walls requires the advice of a structural engineer.

e. Light-weight infill walls can be subtracted freely.

It can be said that the only totally free action that the interior designers can perform is the removal of the lightweight infill walls. Both rigid and light-weight infill walls can be preferred in an open building design. (Habraken, 1998; Leupen, 2005)

\section{ON ADDITIONS TO THE EXISTING BUILDING STRUCTURE}

Students of interior design usually feel free to add new structures to the existing building structure. Linear elements, surfaces or masses can be added to the existing building structure. These additions can be within the structure, outside the structure or they can originate from the inside and extend outside. In structural terms, columns, beams, slabs, stairs and infill walls can be added to the existing structure. Whatever their form, these 
structures can be described as extension systems, because they are added to the existing structure and they are dependent on it. (Mornement, 2007)

a. All these additional structures should be connected only to the joints of the existing building structure.

These additions have to be connected to the existing structure in order to avoid separate behaviour of the old and new structures in the event of an earthquake. They have to be connected to the joints of the existing structure in order to avoid any disturbing load transfer between them. New beams should be connected to existing beam column joints. On the other hand, the additional steel columns should transfer their load to appropriate places in the foundations of the existing structure. If there is no element to transfer this load, this means that the foundations of the existing building also require some extensions. Even the addition of light-weight partition walls require proper connections to the existing structure in order to guarantee their safety during an earthquake.

b. The additional structure should have an order so that a second system, which is connected to the existing building system, can be formed. (Ching, 1996)

Earthquake specifications support the suggestion of this rule. Many earthquake specifications contain statements about the formation of frames within a structure. Planar frames which usually exist in two perpendicular directions should start from one side of the building and end at the other end of it in order to have a consistent frame system. (Ministry of Public Works and Settlement Government of the Republic of Turkey, 2007) It is known that most of the buildings, which collapse in earthquakes, have non-continuous frames in them. (ITU, 1999)

However, structural rules when a change in an existing structure occurs cannot be the same as the structural rules of constructing a new building. The rules of addition are different from the rules of an initial design.

c. Extensions of existing structures should be light-weight structures. (Habraken, 1998; Leupen, 2005)

It is not a good idea to add stone walls irregularly onto existing structures. The additions should not change the centre of gravity of the existing structure so as not to create a twisting instability problem. (Jeong, Elnashai, 2007) It is also not a good idea to add rigid infill walls to the existing structure so as not to create any vertical irregularity problems such as soft and weak storey problems. (Kirac, Dogan, Ozbasaran, 2011)

Thus, interior architecture structures are different from the structures used in architecture. Interior design requires light weight structures such as geodesic domes, bicycle-wheel structures, membranes, suspension structures, steel frames and slabs.

d. All load-bearing additions to the existing building structure require a new structural engineering project as well as a new interior design project.

This structural engineering project should consider both the effect of subtractions from the existing structure and any additions to it. This is the requirement of the basic code of rules of professional ethics, according to which there should not be any difference between a building and the professional project, which was designed for it. Thus, changes in buildings also require professional projects. (Habraken, 1998)

\section{WAYS OF COMPENSATING FOR BROKEN RULES}

Most of the above rules are also valid for non-earthquake regions. The only rules, which apply to earthquake regions and not to non-earthquake regions, are the ones about subtraction and addition of rigid infill walls. Rigid infill walls can be freely subtracted and added in non-earthquake regions, but not in earthquake regions. Thus, there is a considerable difference between architectural design and interior design in earthquake and nonearthquake regions. Thus, open building design in earthquake regions should be based on the use of lightweight infill walls.

According to modern ideology many rules are breakable. Some of the above rules can also be broken in order to achieve certain design objectives. Actually the rules form challenging limits to be broken by modern designers 
and engineers. The only rule, which is unbreakable, is that which requires the production of a new set of interior design and structural design projects, if there is to be any change in the existing, original structure.

In order to break the rules, the rules should be known by the designers. If the rules are broken, they should be compensated for by taking some structural precautions. Such precautions combine design creativity and innovation with each other. Either a new system is designed to compensate for the broken rule (such as the systems which were designed to carry buildings from one place to another place), or rules of a previously invented system are used to compensate for the broken rule. Thus, breaking a rule necessitates the invention of new additional systems which have their own rules.

\section{CONCLUSION}

Investigating ethical values, which affect building activity, cannot be completed without considering the real life process of buildings. Ethics has a lot to do with time. In fact, the major turning points of building ethics can only be achieved through considering the real life process of buildings. Analysis of the above text concerning the rules of earthquake resistant interior design, led the author of this text to derive and formulate the major statements of ethics, which can be discussed in order to develop the basic ethical values for building and construction activity, which also covers the integrated activities of architects, structural engineers and interior designers. These statements are as follows:

a. Freedom is the base of ethics. However freedom does not mean doing whatever one wishes without thinking of others. (Kavas, 1996) People should be free to make small changes in their activities without affecting others negatively. (Heidegger, 1995)

b. Ethics is being open for making changes and accepting changes made by others. (Badiou,2002) This statement does not necessarily conflict with the requirement of consistency in respect of ethical behaviour. One can have a very consistent routine in his/her activities, but still can be open to change in order to produce a better work. (Heidegger, 1995)

c. If the building is designed for change (as an open building or as a piece of time based architecture), with light-weight infill walls, then the interior design of that building can be realized without affecting the structural system. In this case it is possible to complete the interior design only by subtracting and/or adding some light-weight infill walls.

d. If the building is not designed for change and if it is necessary to go beyond removing and adding some light-weight infill walls, then the interior design of that building should be carried out parallel to a structural engineering project designed for it.

e. The rules of earthquake resistant interior design, which are about the physical building, can be broken by compensating for them by using the rules of another system,

f. The rule in respect of the need for a structural engineering project cannot be broken. In other words, the only way of breaking this rule is to redesign the initial architectural project so as to be able to make a change.

The hierarchy between these statements, the different phases in the life time of buildings and the consideration of the co-existence of different professions, which are involved within the building process, can lead towards the development of ethical values for the building activity. For the initial architectural design phase, it is possible to say that:

a. It is ethical for architects to design for change whether they are in an earthquake region or not. Change is needed by everyone. However, designing for change in earthquake regions is even more necessary.

b. Architects who design for earthquake zones should give preference to using light-weight infill walls rather than rigid ones.

c. If there is no obligatory law which prohibits the removal and/or addition of the rigid infill walls freely, then the initial building`s structural engineer should design all necessary levels as soft/weak storey type. It should be known that even the walls of intermediate levels can be removed later.

For the phase of interior design, it can be stated that: 
d. If a building is designed for change, then interior architects should redesign the interiors of it only by removing and/or adding light-weight infill walls.

e. If a building is not designed for change and if it is necessary to go beyond removing and/or adding light-weight infill walls, then it is necessary to have a new structural engineering project for that interior design.

f. All the rules of earthquake resistant interior design, except the rule for the need for a structural engineering project, can be broken by compensating them with the rules of another system.

g. The rules of earthquake resistant interior design should be broken in a systematic way and only for conceptual design purposes. Design alternatives, in which no rules are broken, should also be presented to the clients besides the design alternatives, in which one or more rules are broken.

h. The ethical tendency of structural engineers should be either not to break any rules of earthquake resistant interior design, or to compensate for them in a healthy way.

Since the importance of images is ever increasing, the activities of the professions, such as architecture and interior architecture, which create the built environment, are also expected to increase. On the other hand, because of the contradiction between the technical and artistic issues of design, the artistic quality of design might grow and develop, whilst the technical consciousness may decrease. This could make the ethics of interior design even more critical, as it may start to become nonsensical.

\section{REFERENCES}

Ambrose,J.,Vergun,D., (1993). Seismic Design of Buildings. NY: John Wiley and Sons Inc.

Ambrose,J.,Vergun,D., (1995). Simplified Building Design f0or Wind and Earthquake Forces. NY: John Wiley and Sons.

Ambrose,J.,Vergun,D., (1999). Design for Earthquakes. Canada: John Wiley and Sons Inc.

Aran, K., (2000) Beyond Shelter: Anatolian Indigenous Buildings. Ankara: Tepe Architectural Culture Center.

Athanassiadou, C.J., (2008) "Seismic performance of R/C plane frames irregular in elevation." Engineering Structures. 30(5) pp.1250-1261.

Badiou, A., (2002) Ethics - An Essay on the Understanding of Evil. Trans: Peter Hallward. London, NY: Verso.

Billington, D. P., (1983) The Tower and Bridge, NY: Basic Book Publishers.

Charleson A., (2009) "Comparison between contemporary architectural form in cities with high versus low Seismicity.” Earthquake Spectra. 25(1) pp.1-15.

Ching, F. D.K., (1996) Architecture; Form, Space and Order, NY: Van Nostrand Reinhold.

Comartin, C., Brzev, S., Naeim, F., et al., (2004) "A Challenge to Earthquake Engineering Professionals." Earthquake Spectra. 20(4). pp.1049-1056.

Dowrick, D. (1990). Earthquake Resistant Design. 2nd edition. Essex GB: John Wiley and Sons.

Frampton, K., (2001) Studies in Tectonic Culture: The Poetics of Construction in Nineteenth and Twentieth Century Architecture, Ed:J. Cava. Cambridge. Massachusets: The MIT Press.

Goodwin, G., (1993). Sinan: Ottoman Architecture \& its Values Today. London: Saqi Books.

Habraken, J., (1998) The Structure of the Ordinary - Form and Control in The Built Environment. Ed: J.Teicher. Cambridge Massachusets: The MIT Press. 
Heidegger, M., (1995) Being and Time, (Sein un Zeit) 13 $3^{\text {th }}$ Ed. Trans: J. Macquarrie, E. Robinson. Oxford: Blackwell Publishers.

Hu,Y-X., Liu,S-C., Dong,W., (1996). Earthquake Engineering. Oxford: E and FN Spon.

İTÜ, (1999). http://www.belgenet.com/deprem/depremitu.html (used in 7.2002)

Jeong S.H., Elnashai A.S., (2007) "Fragility Relationship for torsionally imbalanced buildings using three dimensional damage characterization.” Engineering Structures. 29(9) pp.2172-2182.

Kaushik H.B., Rai D.C., Jain S.K., (2009) "Effectiveness of some strengthening options for masonry infilled RC frames with open first storey.” Journal of Structural Engineering- ASCE. 135(8) pp.925-937.

Kavas, Z.O., (1996) The Transformation of the Concept of Freedom in Modern Philosophy. Unpublished PhD Thesis. The Middle East Technical University. Ankara.

Kirac N., Dogan M., Ozbasaran H., (2011) "Failure of weak storeys during earthquakes.” Engineering Failure Analysis. 18(2) pp. 572-581.

Leatherbarrow, D., Mostafavi, M., (2005) Surface Architecture, Cambridge Massachusetts: The MIT Press.

Lee,H.S., Woo,S.W., (2002) "Effect of Masonry Infills on Seismic Performance of a 3 Storey R/C Frame with Non-seismic Detailing.” Earthquake Engineering Structures. 31 (2) February. p.353.

Leupen, Bernard, (2005) “Towards Time Based Architecture.” Time Based Architecture. Eds: B. Leupen, R. Heijne, J. van Zwol. Rotterdam. 010 Publishers.

Lin, T.Y., Stotesbury, S.D., (1981) Structural Concepts and Systems for Architects and Engineers. NY: John Wiley and Sons.

Mainstone, R., (1975) Developments in Structural Form. Massachusets: The MIT Press.

Martin, M., Schinzinger, R., (2005) Ethics in Engineering. $4^{\text {th }}$ Edition. NY: McGraw-Hill Science/Engineering/Math.

Martinezrueda, J.E., Elnashai, A.S., (1995) "A Novel Technique for the Retrofiting of Reinforced Concrete Structures.” Engineering Structures. 17 (5) June. p.359.

Miller, J.T., Reaveley, L.D., (1996) "Historic Hotel Utah Remodel and Upgrade." in Seismic Rehabilitation of Concrete Structures. Ed: Sabnis,G.M., Shroff,A.C., Kahn,L.F. Michigan: ACI.

Ministry of Public Works and Settlement Government of the Republic of Turkey. (2007) Seismic Performance Evaluation of Dual Reinforced Concrete Systems Design According to Turkish Seismic Code. (Trans: E.Y. Karc1) http://www.belgeler.com/blg/22lc/seismic-performance-evaluation-of-dual-reinforced-concretesystems-design-according-to-turkish-seismic-code

Mornement, A., (2007) Extensions. London: Laurence King Publishing Ltd.

Negro, P., Verzeletti, G., (1996) "Effect of Infills on the Global Behavior of R/C Frames." Earthquake Engineering Structures. 25 (8) August. p.253.

Neumann, S., Cowan, R., Compain, F., (n.d.) Film called: Pierre Chareu - La Maison de Verre. Xvid.AC3.Multi-Audio.en.de.fr.www.mvgroup.org (visited on 2010)

Papia, M., Cavaleri, L., Fossetti, M., (2003) "Infilled Frames: Developments in the Evaluation of the Stiffening Effect of Infills.” Structural Engineering Mechanics. 16 (6) December. p.675. 
Paz, M., (1994). International Handbook of Earthquake Engineering. NY: Chapman \& Hall.

Pultar, M., (1997) “A conceptual framework for values in the built environment." Evolving Environmental Ideals: Changing Ways of Life, Values and Design Practices. Ed: M. Grey. Stockholm: Royal Institute of Technology. pp.261-267.

Pultar, M., (2000) "The Conceptual Basis of Building Ethics." Ethics of the Built Environment. Ed: W. Fox. London: Routledge.

Ravichandran, S.S., Klingner, R.E., (2012) "Seismic Design Factors for Steel Moment Frames with Masonry Infills- Part 1.” Earthquake Spectra. 28(3).

Steinbrugge, K.V., (1982) Earthquakes, Volcanos and Tsunamis: An Anatomy of Hazards. NY: Scandia America Group.

Stevens, G., (1998) "Angst in Academia: Universities, the Architecture Schools and the Profession." Journal of Architectural and Planning Research. 15(2). pp. 152-169.

Warner, J., (1996) "Shortcrete in Seismic Repair and Retrofit." in Seismic Rehabilitation of Concrete Structures. Ed: Sabnis, G.M., Shroff, A.C., Kahn, L.F. Michigan: ACl. 